\title{
PENGARUH KUALITAS PRODUK DAN KUALITAS LAYANANAN TERHADAP PEMBELIAN ULANG PELANGGAN PT CARITA SARI PRATAMA.
}

\author{
Kartini Dwi Ambarwati 1) \\ 1) Mahasiswa Program Studi Manajemen FE UNKRIS \\ Amanda Setiorini ${ }^{2)}$ \\ 2) Dosen Program Studi Manajemen FE UNKRIS \\ Alamat: Kampus UNKRIS, Jatiwaringin Jakarta Timur \\ Email: amanda.unkris@ setiorini.net
}

\begin{abstract}
This study aims to determine the effect of product quality and service quality on merchandise repurchases at PT Carita Sari Pratama using quantitative descriptive research. The analytical method used is simple linear regression analysis. The results showed that the product quality and service quality simultaneously and partially had a positive and unidirectional relationship. Meanwhile, the results of the calculation of the correlation coefficient and determination show that there is a very close relationship between the variable product quality and service quality on purchases at PT Carita Sari Pratama.
\end{abstract}

Keywords: product quality, service quality, repurchase

\section{PENDAHULUAN}

Pada zaman globalisasi ini, kecepatan persaingan bisnis menuntut perusahaan untuk bersikap dan bertindak secara kreatif dan inovatif. Peningkatan kualitas produk dan kualitas layanan semakin menjadi perhatian perusahaan. Kualitas produk dan kualitas layanan dapat digunakan untuk salah satu keunggulan yang kompetitif. Kondisi pasar yang kompetitif dan dinamis mengakibatkan setiap perusahaan harus selalu mengamati persaingan dalam lingkungan bisnisnya. Dalam menghadapi lingkungan persaingan yang semakin kuat dan ketat, setiap perusahaan dituntut harus mampu mengoptimalkan sumber daya ekonominya guna meningkatkan daya saing produknya di pasar, serta mampu menjalankan serangkaian strategi pemasaran yang efektif dan selalu mengembangkan strategi pemasaran tersebut secara terus menerus agar dapat menimbulkan pembelian ulang bagi pelanggan.

PT Carita Sari Pratama sebagai badan usaha yang bergerak di sektor jasa. Perusahaan yang menjual berbagai jenis merchandise seperti t shirt, kemeja, polo shirt, jaket, USB, power bank, botol dan lain-lain. Dengan keanekaragaman produk dan model dengan desain sesuai dengan keinginan pelanggan, waktu produksi sangat cepat dan keunggulan bersaing tersendiri terhadap perusahaan lain sejenis. Hal ini yang membuat PT Carita Sari Pratama banyak diminati serta menjadi pilihan yang tepat bagi pelanggan dibandingkan toko sejenis lainnya. Perkembangan penjualan selama 3 tahun ini dalam kondisi menurun. 


\section{LANDASAN TEORI}

\section{Kualitas Produk}

Menurut American Society, kualitas adalah totalitas fitur dan karakteristik suatu produk atau layanan yang memiliki kemampuan untuk memuaskan yang disebut kebutuhan tersirat (Kotler dan Keller; 2016). Menurut Kotler dan Keller (2016), kualitas produk adalah kemampuan suatu barang untuk memberikan hasil atau kinerja yang sesuai bahkan melebihi dari apa yang diinginkan pelanggan. Indikator kualitas produk terdiri atas bentuk, ciriciri produk, kinerja, ketepatan atau kesesuaian, daya tahan, keandalan, kemudahan perbaikan, gaya dan desain.

\section{Kualitas Layanan}

Menurut Tjiptono (2016), kualitas layanan adalah tingkat keunggulan yang diharapkan dan pengendalian atas tingkat keunggulan tersebut untuk memenuhi keinginan pelanggan. Menurut Kotler, kualitas layanan adalah setiap tindakan atau kegiatan yang dapat ditawarkan oleh satu pihak kepada pihak lain, pada dasarnya tidak berwujud dan tidak mengakibatkan perpindahan kepemilikan apapun (Lupiyoadi, 2014). Operasi jasa kemungkinan berkaitan dengan produk fisik atau tidak. Menurut Parasuraman, terdapat faktor yang mempengaruhi sebuah layanan adalah expected service (layanan yang diharapkan) dan perceived service (layanan yang diterima) (Tjiptono, 2016). Indikator kualitas layanan terdiri atas tingkat keunggulan, keinginan pelanggan, keandalan, layanan yang diharapkan, dan daya tanggap.

\section{Pembelian Ulang}

Pembelian ulang menurut Peter dan Olson (2012) adalah kegiatan pembelian yang dilakukan lebih dari satu kali atau beberapa kali, sedangkan menurut Kotler et al (2014), minat beli timbul setelah adanya proses evaluasi alternatif. Dalam proses evaluasi, seseorang akan membuat suatu rangkaian pilihan mengenai produk yang hendak dibeli atas dasar merek maupun minat. Kepuasan yang diperoleh seorang pelanggan, dapat mendorong seseorang untuk melakukan pembelian ulang, menjadi loyal terhadap produk tersebut ataupun loyal terhadap toko tempat dia membeli barang tersebut, sehingga pelanggan dapat menceritakan hal-hal yang baik kepada orang lain. Indikator pembelian ulang terdiri atas minat transaksional, minat referensial, minat preferensial, minat eksploratif, evaluasi, dan alternatif.

\section{METODE PENELITIAN}

\section{Rancangan Penelitian}

Tujuan penelitian ini adalah untuk menganalisis hubungan kausalitas antara kualitas produk dan kualitas layanan dengan pembelian ulang. Data yang digunakan adalah data primer melalui penyebaran kuesioner. Kuesioner merupakan instrumen atau alat yang digunakan dalam penelitian ini. Kuesioner digunakan sebagai alat untuk pengumpulan data. Teknik analisis data yang digunakan adalah analisis regresi linear sederhana dan berganda.

\section{Metode Pengumpulan Data}

\section{Sumber data}

Sumber data yang digunakan adalah data sekunder dan data primer. Data sekunder adalah suatu metode pengumpulan data yang diperoleh dari buku-buku, majalah, jurnal penelitian, dan literatur lain yang relevan dengan masalah penelitian. Data primer adalah data yang mengacu pada informasi yang diperoleh langsung oleh peneliti terkait dengan variabel yang akan menjadi inti 
dalam penelitian. Dengan kata lain, data primer adalah sumber data yang langsung memberikan data kepada pengumpul data (Sugiyono, 2017). Data primer dalam penelitian ini merupakan hasil dari penyebaran kuesioner pada sampel yang telah ditentukan. Dalam penelitian ini adalah jawaban-jawaban yang diberikan oleh responden atas pernyataan yang terdapat pada kuesioner.

Data dalam penelitian ini data dikumpulkan dengan menggunakan metode survei, yaitu dengan menyebarkan angket kepada sampel yang akan diteliti. Dalam penelitian ini digunakan skala semantik diferensial 1-7 untuk mendapatkan data yang bersifat interval. dengan urutan skala 1 menunjukkan bahwa responden sangat tidak setuju terhadap pernyataan yang diberikan, sedangkan angka 7 menunjukkan bahwa responden sangat setuju terhadap pernyataan yang diberikan. Kuesioner dalam penelitian ini dibagikan kepada klien PT Carita Sari Pratama.

\section{Populasi dan Sampel}

Populasi adalah wilayah generalisasi yang terdiri atas obyek atau subyek yang mempunyai kualitas dan karakteristik tertentu yang ditetapkan oleh peneliti untuk dipelajari dan kemudian ditarik kesimpulannya (Sugiyono, 2017). Populasi dalam penelitian ini adalah seluruh pelanggan berupa rekanan (klien) PT Carita Sari Pratama yang berjumlah 60 orang.

Sampel adalah bagian dari jumlah dan karakteristik yang dimiliki oleh populasi tersebut. Dalam penentuan jumlah sampel yang akan diolah dari jumlah populasi, maka harus dilakukan dengan teknik pengambilan sampel yang tepat. Teknik sampling yang digunakan adalah nonprobability sampling. Definisi nonprobability sampling adalah teknik pengambilan sampel yang tidak memberi peluang atau kesempatan sama bagi setiap unsur atau anggota populasi untuk dipilih menjadi sampel. Jenis nonprobability sampling yang digunakan dalam penelitian ini adalah sampling jenuh atau sering disebut juga sensus (Sugiyono, 2017).

Sampling jenuh adalah teknik penentuan sampel bila semua anggota populasi dijadikan sampel, hal ini dilakukan bila jumlah populasi relatif kecil, kurang dari 30, atau penelitian yang ingin membuat generalisasi dengan kesalahan yang sangat kecil. Istilah lain sampel jenuh adalah sensus, dimana semua populasi dijadikan sampel (Sugiyono, 2017). Sedangkan menurut Arikunto (2012), jika jumlah populasi kurang dari 100 orang, maka jumlah sampel diambil secara keseluruhan, tetapi jika populasi lebih besar dari 100 orang, maka bisa diambil $10-15 \%$ atau 20-25\% dari jumlah populasi. Mengingat jumlah populasi tidak lebih besar dari 100 orang responden, sampel yang diambil adalah $100 \%$ dari jumlah populasi yang ada di PT Carita Sari Pratama yaitu sebanyak 60 orang responden. Dengan demikian penggunaan seluruh populasi tanpa harus menarik sampel penelitian sebagai unit observasi disebut sebagai teknik sensus. Objek penelitian dilakukan di PT Carita Sari Pratama, beralamat di Jalan Betok I no. 20, Jati Pulogadung, Jakarta Timur 13220. Adapun penelitian dilakukan Agustus sampai September 2019.

\section{Teknik Analisis Data}

Teknik analisis data yang digunakan dalam penelitian ini adalah analisis regresi linear sederhana dan berganda, yaitu sebagai berikut;

$$
\begin{array}{r}
Y=\alpha_{1}+\beta_{1} X_{1} \ldots \\
Y=\alpha_{2}+\beta_{2} X_{2} \ldots \\
Y=\alpha_{3}+\beta_{1} X_{1}+\beta_{2} X_{2}
\end{array}
$$


di mana;

$$
\begin{array}{ll}
\mathrm{Y} & =\text { Pembelian ulang } \\
\mathrm{X}_{1} & =\text { Kualitas produk } \\
\mathrm{X}_{2} & =\text { Kualitas layanan } \\
\alpha_{\mathrm{i}} & =\text { Konstanta }(\mathrm{i}=1,2,3) \\
\beta_{\mathrm{i}} & =\text { Koefisien regresi }(\mathrm{i}=1,2)
\end{array}
$$

\section{HASIL PENELITIAN DAN PEMBAHASAN}

\section{Hasil Penelitian}

\section{Uji Validitas}

Uji validitas digunakan untuk mengetahui valid atau tidaknya suatu draf isian, jika nilai r-hitung lebih besar dari r-tabel dan nilainya positif, maka butir pernyataan tersebut dikatakan valid (Ghozali, 2016). R-tabel dengan tingkat probabilitas 0,05 adalah 0,2542.

Menunjukkan bahwa variabel kompetensi auditor yang terdiri dari tiga belas butir pernyataan yang diketahui bahwa semua butir pernyataan untuk variabel kualitas produk adalah valid karena memiliki nilai r-hitung yang lebih besar dari r-tabel, sedangkan menunjukkan bahwa variabel kompetensi auditor yang terdiri dari tiga belas butir pernyataan yang diketahui bahwa semua butir pernyataan untuk variabel kualitas layanan adalah valid karena memiliki nilai r-hitung yang lebih besar dari r- tabel. Menunjukkan bahwa variabel kompetensi auditor yang terdiri dari tiga belas butir pernyataan yang diketahui bahwa semua butir pernyataan untuk variabel pembelian ulang adalah valid karena memiliki nilai r-hitung yang lebih besar dari r-tabel.

\section{Uji Reliabilitas}

Uji reliabilitas dilakukan untuk mengetahui sejauh mana hasil konsistensi dari instrumen penelitian. Suatu instrumen penelitian dapat dikatakan reliabel atau konsistensi jika nilai Cronbach Alpha > 0,7. Keandalan konsistensi antar butir atau koefisien keandalan nilai cronbach's alpha, yaitu kualitas produk sebesar 0,838, untuk kualitas layanan sebesar 0,844 , dan untuk pembelian ulang sebesar 0,814 . Dengan demikian dapat disimpulkan semua instrumen penelitian dapat dikatakan reliabel karena mempunyai Cronbach's alpha lebih besar dari 0,7. Hal ini menunjukkan bahwa setiap butir pernyataan yang digunakan sebagai instrumen penelitian mampu memperoleh data yang konsisten yang berarti bila pernyataan tersebut diajukan kembali akan diperoleh jawaban yang relatif sama dengan jawaban sebelumnya.

\section{Analisis Hasil Penelitian}

Tabel 1: Pengaruh Kualitas Produk dan Kualitas Layanan Terhadap Pembelian Ulang Pelanggan PT Carita Sari Pratama

\begin{tabular}{lcccccc}
\hline $\begin{array}{c}\text { Hubungan } \\
\text { Variabel }\end{array}$ & Mult. R & R Square & $\begin{array}{c}\text { Konstant } \\
\mathbf{a}\end{array}$ & $\begin{array}{c}\text { Koef. } \\
\text { Regresi }\end{array}$ & Sig. & A \\
\cline { 2 - 6 } & & & 0,261 & & \\
\hline $\begin{array}{l}\text { Kualitas } \\
\text { Produk }\end{array}$ & 0,665 & 0,429 & 19,259 & 0,479 & 0,000 & 0,05 \\
$\begin{array}{l}\text { Kualitas } \\
\text { Layanan }\end{array}$ & & & & & & \\
\hline
\end{tabular}

Pengujian Signifikansi

F hitung $>\mathrm{F}$ tabel $=21,449>3,159$

Keterangan: Variabel Pembelian_Ulang 
Sumber: data diolah 2020

Berdasarkan Tabel 1, pengujian hipotesis untuk variabel bebas kualitas produk, dan kualitas layanan terhadap pembelian ulang PT Carita Sari Pratama yang menggunakan uji $\mathrm{F}$ terlihat bahwa F-hitung sebesar 21,449, menunjukkan bahwa kualitas produk, dan kualitas layanan terhadap pembelian ulang berpengaruh secara simultan. Nilai $r$ sebesar 0,665, artinya ada hubungan yang positif dan signifikan secara simultan kualitas produk dan kualitas layanan dengan pembelian ulang pelanggan PT Carita Sari Pratama pada tingkat hubungan yang kuat, sedangkan nilai R Square sebesar 0,429, artinya kontribusi yang diberikan kualitas produk dan kualitas layanan secara simultan kepada pembelian ulang pelanggan PT Carita Sari Pratama adalah $42,9 \%$, sisanya sebesar $57,1 \%$ disumbangkan oleh variabel lain yang tidak dibahas seperti kepuasan pelanggan.

Hasil penelitian menunjukkan bahwa persamaan regresi linear berganda adalah sebagai berikut; $Y=19,259+0,261 X_{1}+0,479 X_{2}$. Dari persamaan tersebut, menunjukkan bahwa antara kualitas produk, kualitas layanan secara simultan memiliki hubungan yang positif dan searah. Koefisiensi regresi kualitas produk bertanda positif, artinya jika terjadi peningkatan kualitas produk, maka akan meningkatkan pembelian ulang pelanggan PT Carita Sari Pratama dengan asumsi kualitas layanan tetap. Koefisien regresi kualitas layanan bertanda positif, artinya jika terjadi peningkatan kualitas layanan, maka akan meningkatkan pembelian ulang pelanggan PT Carita Sari Pratama dengan asumsi kualitas produk tetap.

Tabel 2: Pengaruh Kualitas Produk Terhadap Pembelian Ulang Pelanggan PT Carita Sari Pratama

\begin{tabular}{lcccccc}
\hline $\begin{array}{c}\text { Hubungan } \\
\text { Variabel }\end{array}$ & Mult. R & R Square & $\begin{array}{c}\text { Konstant } \\
\text { a }\end{array}$ & $\begin{array}{c}\text { Koef. } \\
\text { Regresi }\end{array}$ & Sig. & $\boldsymbol{\alpha}$ \\
\cline { 2 - 6 } & 0,499 & 0,249 & 39,749 & 0,448 & 0,000 & 0,05 \\
\hline $\begin{array}{l}\text { Kualitas } \\
\text { Produk }\end{array}$ & & & & & & \\
\hline
\end{tabular}

\section{Pengujian Signifikansi}

$\mathrm{t}$ hitung $>\mathrm{t}$ tabel $=4,390>2,002$

Keterangan: Variabel Pembelian_Ulang

Sumber: data diolah 2020

Berdasarkan Tabel 2, nilai r sebesar 0,499, dan R Square adalah 0,249. Nilai r sebesar 0,499, artinya ada hubungan yang positif dan signifikan secara parsial kualitas produk dengan pembelian ulang pelanggan PT Carita Sari Pratama pada tingkat hubungan yang sedang, sedangkan nila R Square sebesar 0,249 , artinya kontribusi yang diberikan kualitas produk secara parsial kepada pembelian ulang pelanggan PT Carita
Sari Pratama adalah 24,9\%, sisanya sebesar $75,1 \%$ disumbangkan oleh variabel lain yang tidak dibahas seperti harga.

Persamaan regresi linear sederhana untuk kualitas produk $\mathrm{Y}=39,749+0,448 \mathrm{X}_{1}$ yang menunjukkan bahwa antara kualitas produk dan pembelian ulang mempunyai hubungan yang positif dan searah. Koefisiensi regresi kualitas produk bertanda positif, 
artinya jika terjadi peningkatan kualitas meningkat pula. produk, maka pembelian ulang akan

Tabel 3: Pengaruh Kualitas Layanan Terhadap Pembelian Ulang Pelanggan PT Carita Sari Pratama

\begin{tabular}{lcccccc}
\hline $\begin{array}{c}\text { Hubungan } \\
\text { Variabel }\end{array}$ & Mult. R & R Square & $\begin{array}{c}\text { Konstant } \\
\text { a }\end{array}$ & $\begin{array}{c}\text { Koef. } \\
\text { Regresi }\end{array}$ & Sig. & $\boldsymbol{\alpha}$ \\
\cline { 2 - 7 } & 0,601 & 0,361 & 27,355 & 0,609 & 0,000 & 0,05 \\
\hline $\begin{array}{l}\text { Kualitas } \\
\text { Layanan }\end{array}$ & & & & & & \\
\hline
\end{tabular}

\section{Pengujian Signifikansi}

$\mathrm{t}$ hitung $>\mathrm{t}$ tabel $=5,726>2,002$

Keterangan: Variabel Pembelian_Ulang

Sumber: data diolah 2020

Pada Tabel 3, didapat nilai $r$ sebesar 0,601 , artinya ada hubungan yang positif dan signifikan secara parsial kualitas layanan dengan pembelian ulang pada PT Carita Sari Pratama pada tingkat hubungan yang kuat, sedangkan nila $\mathrm{R}$ Square sebesar 0,361, artinya kontribusi yang diberikan variabel kualitas layanan secara parsial kepada pembelian ulang pelanggan PT Carita Sari Pratama adalah $36,1 \%$, sisanya sebesar $63,9 \%$ disumbangkan oleh variabel lain yang tidak dibahas seperti kepercayaan.

Persamaan regresi linear sederhana untuk kualitas layanan adalah $\mathrm{Y}=27,355+0,609 \mathrm{X}_{1}$, yang menunjukkan bahwa antara kualitas layanan dan pembelian ulang mempunyai hubungan yang positif dan searah. Koefisiensi regresi kualitas layanan bertanda positif, artinya jika terjadi peningkatan kualitas layanan, maka pembelian ulang akan meningkat pula.

\section{Pembahasan}

\section{Pengaruh Kualitas Produk dan Kualitas Layanan Terhadap Pembelian Ulang Pelanggan PT Carita Sari Pratama}

Penelitian menunjukan bahwa adanya peningkatan kualitas produk dan kualitas layanan secara bersama-sama akan meningkatkan pembelian ulang pelanggan PT Carita Sari Pratama. Peningkatan kualitas produk berarti bahwa produsen dapat memenuhi, bahkan melebihi, harapan pelanggan. Ditambah dengan kualitas layanan yang lebih baik, maka keduanya secara bersama-sama akan meningkatkan kepuasan pembeli.

Produsen yang tidak berhasil memikat konsumen, cenderung akan dilupakan. Dan, meningkatkan kualitas produk dan kualitas layanan secara bersamaan merupakan sebagian cara untuk memikat konsumen dan membuat konsumen mengingat produsen. Hal ini akan membuka peluang untuk terjadinya pembelian ulang di masa mendatang.

Hasil penelitian ini sesuai dengan hasil penelitian yang dilakukan oleh Afif Ghaffar Ramadhan, Suryono Budi Santosa di Semarang (2017) dengan judul Analisis Pengaruh Kualitas Produk, Kualitas Pelayanan, dan Citra Merek terhadap Minat Pembelian Ulang pada sepatu Nike Running di Semarang melalui Kepuasan Pelanggan sebagai variabel intervening, dengan demikian hipotesis pertama diterima. 


\section{Pengaruh Kualitas Produk Terhadap Pembelian Ulang Pelanggan PT Carita Sari Pratama}

Hasil penelitian menunjukan bahwa peningkatan kualitas produk akan meningkatkan pembelian ulang pelanggan PT Carita Sari Pratama. Sesuai dengan definisi Kotler dan Keller (2016) tentang kualitas produk sebagai kemampuan suatu barang untuk memberikan hasil atau kinerja yang sesuai bahkan melebihi dari apa yang diinginkan pelanggan, maka jika kualitas produk meningkat berarti bahwa kemampuan produk untuk memberikan hasil yang sesuai dengan keinginan pelanggan akan semakin tinggi. Dengan terpenuhinya keinginan pelanggan maka kemungkinan untuk melakukan pembelian ulang terhadap produk PT Carita Sari Pratama akan semakin besar. Hasil ini sesuai dengan penelitian yang Rini Kartika Sari, Diah Yulisetiarini, dan Sudaryanto di Jember (2016), berjudul "Pengaruh Harga dan Kualitas Pelayanan Serta Kualitas Produk terhadap Minat Pembelian Ulang dan Kepuasan Pelanggan Online Shopping pada mahasiswa Universitas Abdurachman Saleh Situbondo". Dengan demikian hipotesis kedua diterima.

\section{Pengaruh Kualitas Layanan Terhadap Pembelian Ulang Pelanggan PT Carita Sari Pratama}

Hasil penelitian menunjukan bahwa adanya peningkatan kualitas layanan akan meningkatkan pembelian ulang pelanggan PT Carita Sari Pratama. Definisi kualitas pelayanan menurut Tjiptono (2016) adalah tingkat keunggulan yang diharapkan dan pengendalian atas tingkat keunggulan tersebut untuk memenuhi keinginan pelanggan. Jika produsen dapat meningkatkan keunggulan produk yang dimiliki dan dapat mengendalikan tingkat keunggulan tersebut maka keinginan pelanggan atas produk yang baik akan tercapai. Jika konsumen mendapatkan produk yang sesuai dengan keinginannya, maka kepercayaan terhadap produsen akan meningkat dan kemungkinan konsumen akan membeli kembali di tempat yang sama.

Di sisi lain, Kotler (dalam Lupiyoadi, 2014) mendefinisikan kualitas layanan sebagai setiap tindakan atau kegiatan yang dapat ditawarkan oleh satu pihak kepada pihak lain, pada dasarnya tidak berwujud dan tidak mengakibatkan perpindahan kepemilikan apapun. Jika produsen dapat meningkatkan kualitas layanan berarti bahwa ia menawarkan suatu kelebihan kepada pihak lain, dalam hal ini konsumen. Saat konsumen mempersepsi penawaran tersebut sebagai sebuah kelebihan produsen dibanding produsen yang lain, maka kemungkinan konsumen tersebut untuk melakukan pembelian ulang menjadi lebih besar.

Hasil ini sesuai dengan penelitian yang dilakukan oleh Rini Kartika Sari,Diah Yulisetiarini, dan Sudaryanto di Jember (2016) dengan judul "Pengaruh Harga dan Kualitas Pelayanan Serta Kualitas Produk terhadap Minat Pembelian Ulang dan Kepuasan Pelanggan Online Shopping pada mahasiswa Universitas Abdurachman Saleh Situbondo". Dengan demikian hipotesis ketiga diterima.

\section{KESIMPULAN DAN SARAN}

\section{Kesimpulan}

Dari hasil penelitian yang telah dilakukan terhadap pelanggan PT Carita Sari Pratama dapat disimpulkan sebagai berikut: 1). Secara bersama-sama kualitas produk dan kualitas layanan mendukung peningkatan pembelian ulang pelanggan PT Carita Sari Pratama. 2). Secara sendiri-sendiri kualitas produk mendukung peningkatan pembelian ulang pelanggan PT Carita Sari Pratama. 
3). Secara sendiri-sendiri kualitas layanan mendukung peningkatan pembelian ulang pelanggan PT Carita Sari Pratama.

\section{Saran}

Berdasarkan hasil penelitian dan pembahasan perlu dipertimbangkan untuk memberikan rekomendasi atau saran saran yang mungkin dapat ditindaklanjuti bagi PT.Carita Sari Pratama yaitu sebagai berikut: 1). Kualitas produk sudah dapat diterima oleh para pelanggan, namun untuk lebih meningkatkan pembelian ulang kiranya perusahaan lebih lagi meningkatkan kualitas produk agar para pelanggan tetap memakai produk PT Carita Sari Pratama. 2). Untuk dapat pelanggan terus menggunakan produk PT Carita Sari Pratama, maka harus sering mempromosikan produkproduknya, bisa melalui facebook, instagram, dan melalui media sosial lainnya. 3). PT Carita Sari Pratama harus terus mempertahankan dan meningkatkan kualitas produk dan memberikan produk yang terbaik bagi para pelanggan, mengingat para pelanggan sudah memutuskan menggunakan produk perusahaan tersebut. 4). PT Carita Sari Pratama terus melakukan evaluasi sampai sejauh mana para pelanggan tetap menggunakan produk PT Carita Sari Pratama. 5). Kualitas layanan selalu diterima oleh para pelanggan, namun untuk lebih meningkatkan pembelian ulang kiranya PT Carita Sari Pratama lebih lagi meningkatkan layanan karyawan yang cepat dan terbaik agar para pelanggan tetap memakai produk PT Carita Sari Pratama. 6). Bagi peneliti selanjutnya disarankan untuk menambah variabel-variabel lain yang lebih beragam dalam meneliti dan membahas yang berkaitan dengan pembelian ulang dari perusahaan lainnya.

\section{DAFTAR PUSTAKA}

Arikunto, Suharsimi. (2012). Prosedur Penelitian Suatu Pendekatan Praktik. Jakarta. PT Rineka cipta.

Bothe, Keki R. 1996. Beyond Customer Satisfaction to Customer Loyalty: The Key to Greater Profitability. New York: American Management Association (AMA) Membership Publication Division.

Fandy Tjiptono dan Gregorius chandra. 2016. Service, Quality and satisfaction. Yogyakarta. Andi.

Fandy Tjiptono. 2011. Pemasaran Jasa. Malang. Bayu Media.

Fandy Tjiptono. 2014. Pemasaran Jasa (Prinsip, Penerapan, Penelitian). Yogyakarta. Andi.

Ghozali, Imam. 2016. Aplikasi Analisis Multivariate Dengan Program IBM SPSS 23 (Edisi 8). Cetakan ke VIII. Semarang: Badan Penerbit Universitas Diponegoro.

Kotler, Philip \& Gerry Armstrong, (2014). Principle of Marketing, 15th edition. New Jersey: Pearson Prentice Hall.

Kotler, Philip and Kevin Lane Keller, (2016). Marketing Management, 15th Edition New Jersey: Pearson Prentice Hall, Inc.

Kotler, P., Bowen, J. T., \& Makens, J. C. (2014). Marketing for Hospitality and Tourism. 5 thedition. New Jersey: Pearson Prentice Hall.

Lupiyoadi, Rambat dan A. Hamdani. 2006. Manajemen Pemasaran Jasa. Edisi ke-2. Jakarta: Salemba Empat

Lupiyoadi, R. (2014). Manajemen Pemasaran Jasa. Jakarta: Salemba Empat

Lupiyoadi, Rambat. 2014. Manajemen Pemasaran Jasa Berbasis Kompetensi. Edisi ke-3. Jakarta: Salemba Empat.

Peter, J. Paul \& Olson, Jerry C. 2005. Consumer Behavior Perilaku 
Pelanggan dan Strategi Pemasaran.

Jakarta: Penerbit Erlangga

Saidani, Basrah dan Samsul Arifin, 2012.

Pengaruh Kualitas Produk dan

Kualitas Layanan Terhadap

Kepuasan Pelanggan dan Minat

Beli Pada Ranch Market, Jurnal

Riset Manajemen Sains Indonesia

(JRMSI), Vol. 3, No. 1, 2012

Sugiyono. (2017). Metode Penelitian

Kuantitatif, Kualitatif, dan $R \& D$.

Bandung: Alfabeta, CV.

Sugiyono. (2016). Metode Penelitian

Kuantitatif, Kualitatif dan $R \& D$.

Bandung: PT Alfabet. 